\title{
Ankyloblepharon filiforme adnatum in trisomy 18 (Edwards's syndrome)
}

\author{
D I CLARK AND A PATTERSON \\ From St Paul's Eye Hospital, Old Hall Street, Liverpool L3 9PF
}

SUMMARY Orbital and ocular abnormalities are commonly found in trisomy 18 (Edwards's syndrome). We believe this to be the first case reported in the literature of ankyloblepharon filiforme adnatum (AFA) occurring in Edwards's syndrome, and the literature on AFA is reviewed.

Ankyloblepharon per se describes direct fusion of the lids usually at the lateral canthus and may be congenital or acquired. Ankyloblepharon filiforme adnatum (AFA), however, is a rare congenital abnormality, first described by Von Hasner in $1881,{ }^{\prime}$ in which single or multiple strands of fine connective tissue join the upper and lower lids anywhere along the lid but never at the lateral or medial canthus. ${ }^{2}$ These strands are extensile, and by forcibly opening the lids their length can be almost doubled. ${ }^{3}$ The tissue invariably arises from the 'grey line', anterior to the meibomian gland orifices and posterior to the cilia. ${ }^{+}$

AFA has mainly been reported in association with cleft palate and hare lip, ${ }^{5}$ but it has also been described in a wide spectrum of other congenital abnormalities: hydrocephalus, meningomyelocele, and imperforate anus, ${ }^{6}{ }^{6}$ bilateral syndactyly, ${ }^{7}$ patent ductus arteriosus, ${ }^{8}$ ventricular septal defect, ${ }^{,}$and in association with ectodermal syndromes. " "It usually occurs as a bilateral condition but has been reported as unilateral in a baby with cleft palate. ${ }^{12}$ Furthermore it has been described as an isolated finding in identical twins. ${ }^{13}$ The lid abnormalities reported in trisomy 18 (Edwards's syndrome) are numerous, the most commonly found anomalies being narrow palpebral fissure, ${ }^{14}$ ptosis, and epicanthus. ${ }^{1+15}$ Also described are mongoloid or antimongoloid palpebral fissures, ${ }^{15}$ inability to close the lids, ${ }^{16}$ blepharophimosis, ${ }^{14}$ abnormally long or sparse eyelashes, ${ }^{15} 17$ and abnormally thick lids. ${ }^{16}$ Harley ${ }^{18}$ mentions lid adhesions (that is, ankyloblepharon) as a rare event in trisomy 18 , but this is the first report of AFA associated with this syndrome.

Correspondence to Mr D I Clark, FRCS

\section{Case report}

A $5 \mathrm{lb} 12 \mathrm{oz}(2.6 \mathrm{~kg})$, white female was born at 39 weeks gestation to a 22 -year-old primigravida. The pregnancy was normal and the mother had not taken drugs or been exposed to $x$ rays. There was no family history of congenital abnormalities and no consanguinity. The baby had many abnormal features which were consistent with diagnosis of trisomy 18 , confirmed by chromosomal studies.

The clinical features of note were micrognathia, high arch palate, low set ears, and an odd shaped head. There was overriding of the second and third fingers of both hands and the fifth over the fourth finger of the right hand only. The right foot was inverted, and she had rockerbottom feet and short big toes. The head circumference was $34 \mathrm{~cm}$ at birth.

The right eyelids were joined by one band of expansile tissue, the left eyelids being joined by two such bands (Fig. 1). Other orbital findings were hypoplastic supraorbital ridges, slight epicanthus, and mongoloid slant. She also had abnormally long eyelashes. There were no obvious corneal or lenticular changes, and funduscopy was normal.

As the bands were in the visual axis they were divided as a matter of urgency. No anaesthetic was necessary and little bleeding occurred.

\section{PROGRESS}

At birth the baby was unable to suck and so had to be fed by nasogastric tube. At 6 weeks of age she developed a chest infection and was also found to have an enlarged heart. A two-dimensional electrocardiogram demonstrated a large ventriculoseptal defect. The baby recovered from the chest infection 
Fig. 1 Ankyloblepharon filiforme adnatum in patient with trisomy 18.

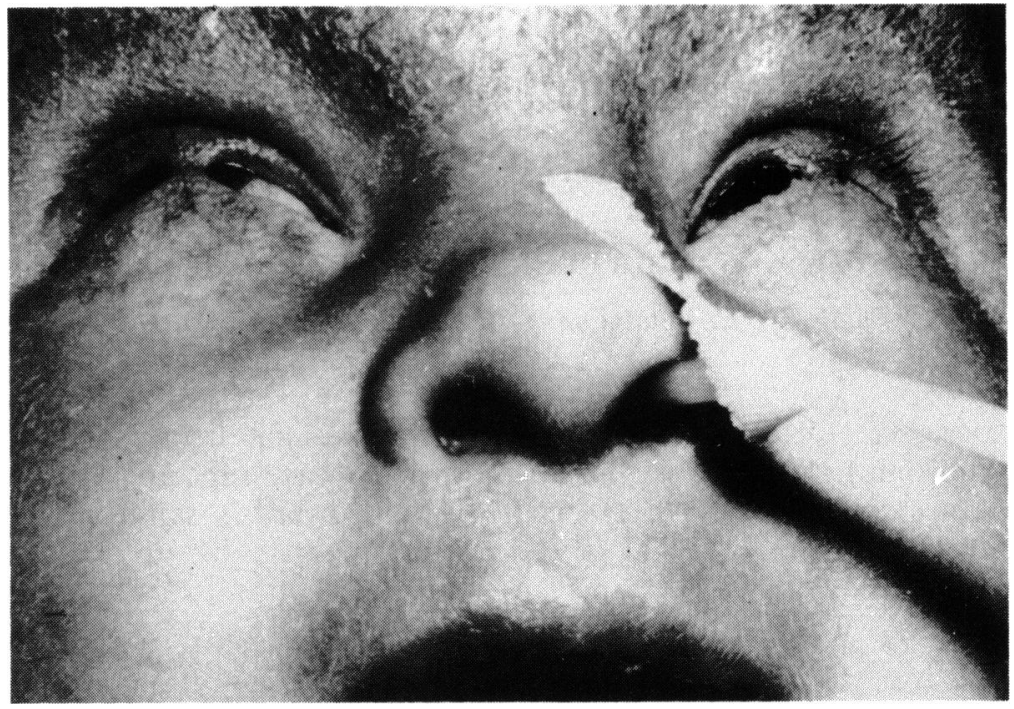

and despite the heart abnormalities and feeding difficulties was coping well. However, the ultimate progress is not good, as few of these children live beyond one year.

\section{Discussion}

The histology of the connective tissue strands has been shown to consist of a vascularised central core surrounded by stratified squamous epithelium. ${ }^{19}$ The aetiology of this abnormality is unknown, and a number of theories have been proposed. Von Hasner thought the lesions were the result of intrauterine inflammation, but this is unlikely for two reasons: firstly, there is no histological evidence of 'inflammation' having occurred, and secondly, despite their close proximity, there is no involvement of the cilia or meibomian glands. Wintersteiner ${ }^{19}$ suggested that trauma by the fingernail of the fetus provoked proliferation of mesodermal tissue. However, this has been refuted because the fingernails of a fetus do not reach the ends of the fingers until the late months of gestation long after fusion of the eyelids has occurred. ${ }^{9}$ It has also been suggested that partial failure of the eyelids to separate is the cause, ${ }^{20}$ but, as the normal temporary eyelid fusion is composed solely of epithelium and complete by the eleventh week of gestation, it is clear that the bands reflect an abnormality in the fusion process and not in separation.

The currently accepted theory is that the condition is due to an interplay of temporary epithelial arrest and rapid mesenchymal proliferation, allowing union of the lids at certain points. ${ }^{21}$

The association of AFA with the ectodermal syndromes would support this theory, as Hay and Wells comment that the syndrome of AFA, ectodermal defects, and cleft lip and palate could be explained by a "defective interaction of ectoderm and mesoderm, probably a fault in mesodermal tissues' ability to organize ectoderm.' ${ }^{\prime \prime}$

It has been postulated ${ }^{22}$ that in trisomy 18 there is abnormal cellular proliferation and hyperplasia which, if applied to the relationship of mesoderm and ectoderm on the lid margin, may have caused the abnormal strands and lend further weight to the theory of Judge et al. ${ }^{21}$

It has been postulated that many cases of AFA are part of the popliteal pterygium syndrome (PPS), comprising cleft lip-palate, popliteal and intercrural pterygia, digital and genital anomalies, and AFA. However, this is unlikely, because despite the variable expressivity of the PPS, AFA occurred only in 3 out of 29 cases presented by Gorlin et al. "

In 1980 Rosenman et al. ${ }^{5}$ divided AFA into four subgroups (Table 1) and indicated that groups I and II were sporadic and groups III and IV were autosomal dominant with variable expressivity. It is not possible to be certain whether our case falls into one of these subgroups or should be placed in a new

Table 1 Classification of ankyloblepharon filiforme adnatum

\begin{tabular}{ll}
\hline Group & Associated abnormalities \\
\hline I & None \\
II & Cardiac or central nervous \\
III & system \\
IV & Ectodermal syndrome \\
\hline
\end{tabular}


subgroup V of AFA and chromosomal abnormalities. It could be included in group II from the cardiac defect or in group IV, as $15 \%$ of trisomy 18 have cleft palate. $^{23}$

We thank Miss Elizabeth A Wreyford and Miss Gillian Doherty for typing the manuscript, and Mr C Mody for photographic assistance.

The chromosomal studies were carried out at the Cytogenetic Laboratory, the Royal Liverpool Hospital.

\section{References}

1 Von Hasner. Ankyloblepharon filiforme adnatum. Z Heilkd $1881 ; 2: 429$.

2 Duke-Elder S. System of ophthalmology. London: Kimpton, 1964; 3: 869-71.

3 Weill S. Arch Auken Heilk 1908; 59: 278. Cited by Duke-Elder S. System of ophthalmology. London: Kimpton, 1964; 3: 869.

4 Khanna VN. Ankyloblepharon filiforme adnatum, Am J Ophthalmol 1957; 43: 774-7.

5 Rosenman Y, Ronen S, Eidelman AI, Schimmel MS, Ankyloblepharon filiforme adnatum. Am J Dis Child 1980; 134: 751-3.

6 Kayarian EL, Goldstein P. Ankyloblepharon filiforme adnatum with hydrocephalus, meningocele and imperforate anus. $\mathrm{Am} \mathrm{J}$ Ophthalmol 1977; 84: 355-7.

7 Akkermans C, Stern LM. Ankyloblepharon filiforme adnatum. Br J Ophthalmol 1979; 63: 129-31.

8 Lobstein A, Haarscher A. Ankyloblepharon filiforme congénital et malformation cardiaque associćc. Bull Soc Ophtal Mol Fr $1953 ; 2: 128-31$.
9 Rogers JW. Ankyloblepharon filiforme adnatum. Arch Ophthalmol 1961; 65: 114-7.

10 Hay RJ, Wells RS. The syndrome of ankyloblepharon, ectodermal defects and cleft lip and palate: an autosomal dominant condition. Br J Dermatol 1976; 94: 277-89.

11 Gorlin RJ, Sedano HO, Cervenka J. Popliteal pterygium syndromc. Pediatrics 1968: 41: 503-9.

12 Kapoor MS, Sood GC, Aurora AL, Kapoor S. Unilateral ankyloblepharon filiforme adnatum. Indian J Ophthalmol 1977; 25: 43-4.

13 Howe J, Harcourt B. Ankyloblepharon filiforme adnatum affecting identical twins. BrJ Ophthalmol 1974; 58: 630-2.

14 Howard RO. Classification of chromosomal eye syndrome. Int Ophthalmol 1981; 4: 77-91.

15 Ginsberg J, Perrin E, Sueoka W. Ocular manifestation of trisomy 18. Am J Ophthalmol 1968; 66: 59-67.

16 Calderstone JP, Cliess J, Borodic G, Albert D. Intraocular pathology of trisomy 18. Br J Ophthalmol 1983; 67: 162-9.

17 Weber WW, Mamvness P, Day R, Miller P. Trisomy 17-18 studies in longterm survival. Pediatrics 1964; 14: 533-41.

18 Harley RD. Pediatric ophthalmology. Philadelphia: Saunders, 1983.

19 Wintersteiner H (1908). Ein neuer Fall von Ankyloblepharon filiforme. Arch Augenheilkd 1908; 59: 196.

20 Mattson R. Ankyloblepharon filiforme adnatum. Acta Ophthalmol (Kbh) 1950; 28: 223-7.

21 Judge $H$, Mott W, Gabriels J. Ankyloblepharon filiforme adnatum. Arch Ophthalmol 1929; 2: 702-8.

22 Ginsberg J, Bove K, Nelson R, Englander GS. Ocular pathology of trisomy 18. Ann Ophthalmol 1971; 3: 273-9.

23 Gorlin RJ, Cervenda J, Prugansky S. Birth Defects 1971; 7: 25. 